\title{
Vesicovaginal Fistulas: Anatomical Clinical and Surgical Aspects in the Conakry University Hospital Center
}

\author{
Abdoulaye Bobo Diallo1,2*, Thierno Mamadou Oury Diallo1, Ibrahima Bah1, \\ Mamadou Diawo Bah1, Mamadou 2 Barry1, Daouda Kanté1, Oumar Raphiou Bah1, \\ Sékou Guirassy ${ }^{1}$, Mamadou Bobo Diallo' ${ }^{1}$ \\ ${ }^{1}$ Urology and Andrology Unit, University Teaching Hospital Conakry, Conakry, Guinée \\ ${ }^{2}$ Service d'Urologie-Andrologie, CHU Conakry, Conakry, Guinée \\ Email: *abobodiallo@gmail.com
}

Received 7 November 2015; accepted 15 December 2015; published 18 December 2015

Copyright (C) 2015 by authors and Scientific Research Publishing Inc.

This work is licensed under the Creative Commons Attribution International License (CC BY).

http://creativecommons.org/licenses/by/4.0/

c) (7) Open Access

\begin{abstract}
Objective: To analyze the management of VVF in the Service of Urology-Andrology Obstetrics and Gynecology of the University Hospital in Conakry. Materials and Methods: From January 2012 to December 2013, 152 patients with a mean age of 30 years (14 - 80 years) were hospitalized in the Departments of Urology-Andrology and Gynecology-Obstetrics of the Conakry University Hospital Center. Clinically fistulas were divided according to the classification of Benchekroun as single, complex and complicated. The fistulas were diagnosed after a minimum period of three months and the results were assessed with a mean follow-up of 7 months (range 3 to 10 months) according to the following criteria: complete healing, intermediate healing and failure. Results: Fistulas occur mainly in young multiparous women. The obstetric etiology was dominant (98\%). Clinically, there were $30 \%$ simple fistulas, $46 \%$ complex fistulas and $24 \%$ of complicated fistulas. From a therapeutic standpoint, the treatment consisted of a single fistulorraphie (Chassar Moir) in $82 \%$ of cases and a fistulorraphie with interposition of healthy tissue in $18 \%$ of cases. After a mean follow-up of 7 months we obtained a healing in $62 \%$ of cases, a failure in $31 \%$ of cases and the results were intermediate in $\mathbf{7 \%}$ of cases. Conclusion: It appears that the VVF represents a public health concern in Guinea and surgical treatment is technical difficult due to the higher frequency of complex fistulas.
\end{abstract}

\section{Keywords}

Vesico-Vaginal Fistulas, Epidemiology, Treatment

"Corresponding author.

How to cite this paper: Diallo, A.B., Diallo, T.M.O., Bah, I., Bah, M.D., Barry, M., Kanté, D., Bah, O.R., Guirassy, S. and Diallo, M.B. (2015) Vesicovaginal Fistulas: Anatomical Clinical and Surgical Aspects in the Conakry University Hospital Center. Open Journal of Urology, 5, 224-230. http://dx.doi.org/10.4236/oju.2015.512036 


\section{Introduction}

Vesicovaginal fistula (VVF) is as an abnormal and more or less complex acquired communication between the lower urinary tract and genital tract. In addition to the medical sequelae, these fistulas represent a real psychosocial drama for the women with VVF [1]. It is still considered a common disease in developing countries. The WHO has estimated that about 3 million women have obstetric fistula worldwide, with 50 - 130,000 new fistulas reported each year [2]. In the developed countries, the most common etiologies of VVF include gynecological surgery injuries, pelvic surgery or radiotherapy lesions [3], whereas, in developing countries, particularly in Africa, obstetric causes are the predominant etiology [1] [4]-[6]. For decades, urologists have faced problems in treating VVF. Hence, many researchers have provided different surgical procedures for treatment of VVF. Therefore, the aim of this study was to analyze the management of VVF in the Department of Urology and Andrology Gynecology-Obstetrics of the University Hospital of Conakry.

\section{Patients and Methods}

This retrospective study was conducted at the University Hospital of Conakry. The study included 152 VVF patients diagnosed and treated in the Department of Urology, Andrology and Gynecology and Obstetrics of the University Hospital of Conakry during January 2012 and December 2013. The complete medical records of all patients including clinical and operative data and postoperative follow-up of at least three months were obtained. In the case of patients who had undergone multiple operations for VVF in the past, only the last operation was considered for the study.

Epidemiological, clinical and therapeutic variables were studied. We used Benchekroun's [4] classification of fistulas to classify the fistulas as follows:

- Simple Fistulas: These are variably-sized fistulas of the septum near the ureteral orifices respecting the urinary continence system without sclerosis.

- Complex Fistula: In this case, the fistulas have reached the urinary continence system, affecting the bladder neck, and the urethra is more or less involved. There is also a moderate peri-fistular sclerosis.

- Complicated fistulas: These are fistulas associated with impairment of urinary continence system as well as damage to the bladder neck and urethra and multiple major peri-fistular sclerosis. These fistulas are also commonly associated with a rectovaginal fistula.

All the surgical techniques used involved a surgical repair in order to restore the bladder capacity and voiding function. Vaginal, abdominal or mixed surgical approach was used. The abdominal approach was recommended in high fistulas that were virtually inaccessible through the vagina. In cases where the urethra, bladder neck or trigone were impaired, the vaginal route was preferred for direct access to the lesions and sampling of the interposing tissue between the bladder and vaginal sutures. Simple fistula was closed by performing a simple fistulorraphy as per Chassar Moir (for simple fistula) by urethrovesical anastomosis or urethroplasty using a bladder flap. In the case of complex and complicated fistulas, vaginal tissue was used for closure of fistulas. Interposition of healthy tissue (labial skin flap, vaginal or fatty from Martius) was performed in wide fistulas that do not allow direct suture.

Preferred therapeutic results after a follow-up of at least three months were judged according to the following criteria:

- Healing: total absence of loss of urine with intact urination after the fistulorraphie.

- Intermediate stage: Presence of stress urinary incontinence after the closure of the fistula or when there was pollakiuria associated with the reduction in bladder capacity.

- Failure: Persistence of the total loss of urine after surgical treatment.

\section{Results}

The age of the patients ranged from 14 to 80 years, with an average of 30.5 years. At the time of occurrence of the fistula, $65 \%(n=99)$ patients were over 20 years (Table 1). Regarding the socio-professional category, 91\% of patients were housewives and $72 \%(n=109)$ of women were married (Table 2). About $76.3 \%$ of patients were affected with VVF for more than one year. A total of $65 \%(n=99)$ of the VVF were never operated while $35 \%(n=53)$ had received at least one prior fistulorraphie. The etiology of VVF was obstetrical in $98 \%(n=149)$ and surgical ( 2 surgical treatment of uterine prolapse and one induced abortion) in $2 \%(n=3)$ patients. A total of 
Table 1. Clinical and demographic datas distribution.

\begin{tabular}{|c|c|c|}
\hline Demographic and clinical datas & Number of cases & Percentage \\
\hline \multicolumn{3}{|l|}{ Age interval } \\
\hline 11 - 20 years & 53 & 35 \\
\hline 21 - 30 years & 58 & 38.1 \\
\hline 31 - 40 years & 27 & 17.7 \\
\hline $41-50$ years & 12 & 7.9 \\
\hline 51 - 60 years & 1 & 0.65 \\
\hline 71 - 80 years & 1 & 0.65 \\
\hline \multicolumn{3}{|l|}{ Parity } \\
\hline Nulliiparous & 2 & 1.31 \\
\hline Primiparous & 57 & 37.5 \\
\hline Multiparous & 93 & 61.18 \\
\hline \multicolumn{3}{|l|}{ Birth location $(n=149)$} \\
\hline Home & 57 & 38.25 \\
\hline Health care facility & 92 & 61.74 \\
\hline \multicolumn{3}{|l|}{ Birth method $(n=149)$} \\
\hline Vaginal & 92 & 61.74 \\
\hline Cesarean & 57 & 38.25 \\
\hline
\end{tabular}

Table 2. Marital status distribution.

\begin{tabular}{ccc}
\hline Marital status & Number of cases & Percentage \\
\hline Maried & 109 & 71.7 \\
Separate & 20 & 13.2 \\
Divorced & 12 & 7.9 \\
Widow & 9 & 5.9 \\
Single (never married) & 2 & 1.3 \\
Total & 152 & 100 \\
\hline
\end{tabular}

$61.1 \%$ of patients were multiparous, $37.5 \%$ primiparous, and $1.3 \%$ was nulliparous. Around $62 \%$ of women with obstetric fistula gave birth in a health-care facility. On the 149 cases of obstetrical etiology, childbirth was done vaginally in $61.7 \%(n=92)$ and cesarean in 38.2\% $(n=57)$. In 1 patient, childbirth was done vaginally with forceps application. The average length of the labor was 3.6 days (range, 1 - 10 days). Clinically, 30\% (n = 46) patients had simple fistulas, $46 \%(n=70)$ patients had complex fistulas, and $24 \%(n=36)$ had complicated fistula. The distribution of fistulas based on the anatomic type is listed in Table 3. Injury of the continence system (cervical, cervical-urethral and/or transection urethral) due to VVF (trigonal and retro-trigonal) was observed in $70 \%(\mathrm{n}=106)$ and $30 \%(\mathrm{n}=46)$ patients, respectively.

From a therapeutic point of view, the vaginal route was the most used in our patients, i.e., in 96.7\% $(n=147)$ patients. Surgical treatment consisted of a fistulorraphie by vesico-vaginal duplication and excision of sclerotic edges (Chassar Moir) in 82\% ( $\mathrm{n}=125)$ patients and a fistulorraphie with interposition of healthy tissue (flap Martius or cutaneous fat flap the labia majora) in $18 \%(n=27)$ cases. 
Bladder drainage was ensured in all cases by a urethral Foley probe type $\mathrm{CH} 18$, and the average length of the drainage was 16 days (range, 7 to 21 days).

A mean follow-up of 7 months (range 3 to 10 months) showed that $62 \%(n=94)$ of cases were cured, $31 \%(n$ $=47)$ of cases showed failure, and $7 \%(n=11)$ cases were in the intermediate stage. The best results were obtained in cases with simple fistulas (37 healings out of 46 fistulas). Urinary incontinence after fistulorraphie was observed in complex fistulas, and failures were noted in complicated fistulas, with 20 failed fistulas out of 36 fistulas (Table 4).

\section{Discussion}

VVF is a major public health problem in young rural women. The average age of patients in our study is in accordance with a previous study by Guirassy et al. [7], who also reported patients with an average age of 30 years (range, 15 - 60 years). However, our average age is higher compared to those noted by Kanyi et al. [5], Nguembi et al. [8], and Kambou et al. [9] in their series (i.e., 20, 28, 14, and 17 years, respectively). Moudouni et al. [1] reported patients with an average age of 33 years (range, 17 - 76 years).

In the genesis of obstetric VVF, the dystocic labor in young women remains the most incriminating factor. However, in our study, this factor did not play a major role since over $65 \%$ of patients were over 20 years at the time of onset of fistula. This is in accordance with previous studies by Gueye et al. [10] in Senegal (70\%) and Qi et al. [11] in Kati, Mali (82\%). However, Harouna et al. [12] and Ibrahim et al. [13] have noted that 52\% of patients aged less than 20 years. In our study, almost all patients (98\%) did not attend any modern schools. A total of $71.7 \%$ of cases in our series were married, but they were unemployed with no income earning activities. Sombie et al. [14] found that Burkina Faso patients with fistulas usually had no paid employment.

According to a demographic and health survey, i.e., EDSG-III [15], conducted in 2005 in Guinea, $72 \%$ of women with fistula had never attended school; in other words, the less the scholarity, the higher the rate of fistula. Hence, it can be said that the level of education and the socio-economic situation are factors that contribute to the occurrence of VVF.

Table 3. Anatomical types distribution.

\begin{tabular}{ccc}
\hline Fistula type & Number of cases & Percentage [95\% CI*] \\
\hline Retro-trigonal & 34 & $22.4[8.4$ and $36.4 \%]$ \\
Trigonal & 12 & $7.9[-7.4$ and $23.2 \%]$ \\
Trigono-cervical & 14 & $9.2[-5.9$ and $24.3 \%]$ \\
Trigono-cervico-uretral & 4 & $2.6[-13$ and $18.2 \%]$ \\
Trigono-cervico-uretral + transection & 36 & $23.7[9.8$ and $37.6 \%]$ \\
Cervical & 35 & $23.1[9.1$ and $37.1 \%]$ \\
Cervico-uretral & 17 & $11.1[-3.8$ and $28 \%]$ \\
Total & $\mathbf{1 5 2}$ & $\mathbf{1 0 0}$ \\
\hline
\end{tabular}

$\mathrm{CI}^{*}$ : Confidence interval.

Table 4. Surgical results for each class of fistula.

\begin{tabular}{|c|c|c|c|c|}
\hline \multirow{2}{*}{ Fistula type } & \multicolumn{3}{|c|}{ Surgical results } & \multirow{2}{*}{ Total } \\
\hline & Healing & Intermédiate & Failure & \\
\hline Simple & 37 (24.3\%) & $2(1.3 \%)$ & 7 (4.6\%) & 46 (30.3\%) \\
\hline Complexe & 43 (28.3\%) & 7 (4.6\%) & 20 (13.2\%) & 70 (46\%) \\
\hline Complicated & 14 (9.2\%) & $2(1.3 \%)$ & 20 (13.2\%) & 36 (23.7\%) \\
\hline Total & $94(61.8 \%)$ & $11(7.2 \%)$ & $47(31 \%)$ & $152(100 \%)$ \\
\hline
\end{tabular}


Obstetrical etiology was predominant in our series. This is in accordance with many African studies [1] [4] [8] [10]. Cortesse [3] reported that in developed countries, obstetric fistula has virtually disappeared; in his study, $90 \%$ of VVF cases followed a benign gynecologic surgery and 10\% had complications of pelvic cancer surgery, radiation of the pelvis, and localized infections.

VVF are not frequent among primiparous. In the present study, it was found that VVF was most frequent in multiparous patients (in 61.1\% cases); this is also consistent with those reported by Gueye et al. [10] and Moudouni et al. [1], i.e., 53\% and 72.5\% of cases, respectively. Traditional child birth at homes is recognized as a predictor of VVF in our study as well in that of Ouattara et al.'s [16] study, i.e., in both studies, births took place in a health care facility in $62 \%$ and $65.6 \%$ of cases, respectively. It must be emphasized that in our study, the birth followed a long labor, which started at home, and the patients could not travel to a health facility in the early hours of labor given the distance or a lack of transportation means. Furthermore, Harouna et al. [12] reported an average of four days of labor. Qi et al. [11] reported that 85.3\% of patients had more than 3 days of work. In Ouattara et al.'s [16] study, 63.4\% of VVF cases gave birth after 48 hours of work.

In our study, a predominance of complex fistulas was noted; this is associated to the long-duration of labor and delivery. Mensah et al. [17] and Gueye et al. [10] reported 54\% and 70\% of cases of simple fistulas, respectively.

The treatment of VVF is difficult; hence, many treatment techniques have been proposed [1] [3] [18] [19] with an aim to restore both the bladder continence and voiding function. In our study, the fistulorraphie was considered at least three months after the diagnosis, and vaginal surgical approach was preferred for most patients. This surgical approach was also adopted by many researchers, including Kambou et al. [9], Moudouni et al. [1], Ouattara et al. [16], and Falandry [20] in the respective proportions of $61.4 \% ; 70 \% ; 89.5 \%$ and $100 \%$.

The vaginal route remains the best way for us because it allowed perfect exposure of the fistula when traction is induced on the balloon of a Foley catheter. Technically, a simple fistulorraphie by vesicovaginal duplication and excision of the sclerotic edges was performed in 82\% of patients. Qi et al. [11] used this technique in 85.3\% of their patients. A fistulorraphie with interposition of normal tissues was used in 18\% of patients. Falandry [20] reported 29 interpositions using the method of Martius out of 247 surgical procedures, and 8.77\% patients in Moudouni et al.'s [1] study benefited from the same technique.

Different researchers have reported different bladder drainage techniques after fistulorraphie. Our study involved a bladder drainage closed with a urethral Foley-type probe. The urine drainage by a cystostomy tube was preferred by Moudouni et al. [1] in 14\% of cases. Couvelaire [21] advocated urine drainage by urethral probe in the case of high fistulas far from the neck and by cystotomy in cervical and urethral fistula. Falandry [20] [22] [23] reported bladder drainage by urethral catheter for 10 to 12 days in all series.

Although the treatment outcomes observed in our series were significant, they are far from satisfactory, especially as two in five patients showed failure in their fistula treatment. However, our results are similar to those of Kambou et al.'s [9] with an overall success rate of $73.70 \%$ and Moudouni et al.'s [1] with 67\% cure rate, $8 \%$ of urine incontinence, and 25\% of failure. Ouattara et al. [16] noted 71.6\% cure rate, approximately $29.9 \%$ failure; they found that the results are less satisfactory in the case of vesico-cervico-urethral fistulae with $48.34 \%$ success against $76.2 \%$ for the fistula of the vesico-vaginal septum. Falandry [20], with 6 months of minimum follow-up, achieved healing in $62.4 \%$ cases, and the success was constant from the first intervention in the simple fistulas with $92.8 \%$ success rate. This success rate was $76.1 \%$ in complex fistulae and $16.6 \%$ in severe fistulas transection. In our study, we did not observe any relationship between the duration of the fistula and the therapeutic outcome; the only one pejorative factor was the type of fistula. The more the seriousness of the fistula, the more uncertain was its complete recovery.

\section{Conclusions}

VVFs are a major cause of morbidity and therefore, a public health concern in our country. These exceptional surgically-treated fistulas occur among women of childbearing age. The low level of education, poverty, lack of infrastructure and trained personnel, especially in rural areas, are the contributing factors to the occurrence of VVFs. Surgical treatment of VVFs presents many technical difficulties due to the high frequency of complex and complicated fistulas. Healing is easily achieved in the case of simple fistulas, but complex and complicated ones require the use of interposition or additional surgical techniques and/or multiple interventions.

Thus, there is a need for planning of vast public health management policies for preventive, educational and curative activities of VVFs. 


\section{References}

[1] Moudouni, S., Nouri, M., Koutani, A., Ibn Attya, A., Hachimi, M. and Lakrissa, A. (2001) Obstetrical Vesico-Vaginal Fistula. Report of 114 Cases. (Les fistules vésico-vaginales obstétricales. À propos de 114 cas.) Progres en Urologie, 11, 103-108.

[2] Benchekroun, A., El Alj, H.A., El Sayegh, H., Lachkar, A., Nouini, Y., Benslimane, L., Belahnech, Z., Marzouk, M. and Faik, M. (2003) Vesico-Vaginal Fistula. Report of 1050 Cases. (Les fistules vesico-vaginales: À propos de 1050 cas.) Annales d'Urologie, 37, 194-198. http://dx.doi.org/10.1016/S0003-4401(03)00053-6

[3] Cortesse, A. and Colau, A. (2004) Vesico-Vaginal Fistula. (Fistule Vésico-Vaginale.) Annales d Urologie, 38, 52-66. http://dx.doi.org/10.1016/j.anuro.2004.01.001

[4] Benchekroun, A., Lakrissa, A., Essakali, H.N., Faik, M., Abbaka, T., Hachimi, M., Marzouk, M. and Benabderrazek, T. (1987) Vesico-Vaginal Fistula. Report of 600 Cases. (Les fistules vésico-vaginales à propos de 600 cas.) Journal of Urology, 93, 151-158.

[5] Zoung-Kanyi, J. and Sow, M. (1990) Focus on Vesicovaginal Fistulas at the Yaoundé Central Hospital. Report of 111 Cases Seen in 10 Years. (Le point sur les fistules vésico-vaginales à l’hôpital central de Yaoundé. À propos de cent onze cas observés en dix ans.) Annales d Urologie (Paris), 24, 457-461.

[6] Anoukoum, T., Attipou, K.K., Agoda-Koussema, L.K., Akpadza, K. and Ayite, E.A. (2010) Epidemiological, Aetiological and Treatment Aspects of Obstetrical Fistula in Togo. (Aspects épidémiologiques, étiologiques et thérapeutiques de la fistule obstétricale au Togo.) Progres en Urologie, 20, 71-76. http://dx.doi.org/10.1016/j.purol.2009.08.038

[7] Guirassy, S., Diallo, I.S., Bah, I., Diallo, M.B., Sow, K.B., Diabate, I., Kaba, A. and Balde, A. (1995) Epidemiologic and Therapeutic Features of Urogenital Fistulae in Guinea (Conakry). (Aspects épidémiologiques et thérapeutiques des fistules uro-génitales en Guinée.) Progres en Urologie, 5, 684-689.

[8] Nguembi, E., Sepou, A., Yanza, M.C., Denissio, M., Mbalackpo, B., Ngbale, R., et al. (2005) Obstetric Fistula Neglected Disease: Report of 62 Cases Observed in Bangui (Central African Republic). (La fistule obstétricale, pathologie négligée: À propos de 62 cas observés à Bangui Centrafrique.) Revue Médecine d'Afrique Noire, 52, 593-597.

[9] Kambou, T., Zango, B., Ouattara, T.A., Dao, B. and Sanou, D. (2006) Update on the Management of Urogenital Fistulas Souro Sanou University Hospital in Bobo Dioulasso: Study 57 Cases Operated in 2 Years. (Point sur la prise en charge des fistules uro-génitales au CHU de Souro Sanou de Bobo Dioulasso: Etude de 57cas opérés en 2 ans.) Revue Médecine d'Afrique Noire, 53, 665-673.

[10] Gueye, S.M., Ba, M., Sylla, C., Diagne, B.A. and Mensah, A. (1992) Vesicovaginal Fistulas. Etiopathogenic and Therapeutic Aspects in Senegal. (Les fistules vésico-vaginales: Aspects étiopathogeniques et thérapeutiques au Sénégal.) Journal d'Urologie, 98, 148-151.

[11] Qi, L.Y., Ouattara, Z. and Ouattara, K. (2000) Traitement des fistules vésico-vaginales à l’hôpital de Kati. À propos de 34 cas. Médecine d'Afrique Noire, 47, 116-119.

[12] Harouna, Y.D., Seibou, A., Maikano, S., Djambeidou, J., Sangare, A., Bilane, S.S., et al. (2001) The VVF Obstetric Cause: Survey of 52 Women Admitted to the Village of Fistula. [La fistule vésco-vaginale de cause obstétricale: Enquête auprès de 52 femmes admises au village des fistuleuses.] Médecine d'Afrique Noire, 48, 55-59.

[13] Ibrahim, T. and Sadiq, A.U. (2000) Daniel SO Caracteristics of VVF Patients as Seen at the Specialist Hospital. West African Journal of Medicine, 19, 59-63.

[14] Sombié, I., Kambou, T., Conombo, S.G., Ouedraogo, L., Zoungrana, T., Hounton, S. and Meda, N. (2007) Retrospective Study of Urogenital Fistula in Burkina Faso from 2001 to 2003. [Bilan rétrospectif des fistules urogénitales obstétricales de 2001 à 2003 au Burkina Faso.] Medecine Tropicale, 67, 48-52.

[15] Direction Nationale de la Statistique (DNS) (Guinée) et ORC Macro (2006) Enquête Démographique et de Santé, Guinée 2005. DNS et ORC Macro, Calverton.

[16] Ouattara, K., Traore, M.L. and Cissé, C. (1991) Some Statistical Aspects of VVF Republic of Mali. About 134 Cases. [Quelques aspects statistiques de la fistule vésico-vaginale République du Mali. A propos de 134 cas.] Médecine d'Afrique Noire, 38, 856-860.

[17] Mensah, A., Ba, M., Gueye, S.M., Sylla, C., Ndoye, A.K., Moreira, P., Fall, A. and Labou, I. (1996) Neurologic Aspects of Vesico-Vaginal Fistula of Obstetrical Origin. [Les aspects neurologiques de la fistule vésico-vaginale d'origine obstétricale.] Progrès en Urologie, 6, 398-402.

[18] Mhiri, M.N., Rekik, S., Trifa, M. and Bouzid, F. (1993) Urogenital Lesions and Fistulas. What's Going on in Tunisia? [Plaies et Fistules uro-génitales. Qu'en advient-il en Tunisie?] Journal de Gynécologie Obstétrique et Biologie de la Reproduction, 22, 157-161.

[19] Dumurgier, C. and Falandry, L. (2012) Surgical Management of Obstetric Fistulae. [La chirurgie des fistules obstetriccales.] Bulletin de l'Academie Nationale de Medecine, 196, 1535-1556. 
[20] Falandry, L. (1992) Treatment of Post-Partum Urogenital Fistulas in Africa. 261 Cases Observed in 10 Years. [Traitement des fistules uro-génitales post-partum en Afrique. 261 cas observés en dix ans.] Progrès en Urologie, 2, 861-873.

[21] Couvelaire, R. (1982) Complex Vesicovaginal Fistulas. [Les fistules vésico-vaginales complexes.] Journal of Urology, 88, 353-358.

[22] Falandry, L. (1992) Vesicovaginal Fistula in Africa. 230 Cases. [La fistule vésico-vaginale en Afrique. 230 observations.] La Presse Médicale, 21, 241-245.

[23] Falandry, L., Lahaye, F. and Marara, C. (1990) A Pedicled Musclefat Flap of the Major Labia in the Treatment of Complex Vesicovaginal Fistula. Apropos of 11 Cases. [Le lambeau pédiculé cutanéo-graisseux de la grande lèvre dans le traitement des FVV complexes. A propos de 11 cas.] Journal of Urology, 96, 97-102. 